\title{
Tulevien numeroiden kirjoittajakutsut
}

\author{
Aikuiskasvatus katsoo teemanumeroissaan laajasti yhteiskuntaan. \\ Osallistu tieteenalojen rajat ylittävään keskusteluun omalla tekstillä.
}

\section{AIKUISKOULUTUSPOLITIIKKA, 4/2020}

Mitä sanottavaa kasvatustieteen ja aikuiskasvatustieteen tutkijoilla on Suomen aikuiskoulutuspolitiikasta?

Koulutuspolitiikkaan tuli 2010-luvun lopulla jatkuvan oppimisen käsite. Hallitusohjelmaan taas sisältyy jatkuvan oppimisen uudistaminen, jossa korostuvat työurien pidentäminen, työllisyyden parantaminen, julkistalouden tasapaino sekä yritysten kilpailukyvyn ja tuottavuuden parantaminen.

Aikuisten kouluttamista sanoitetaan pitkälti työelämän, elinkeinopolitiikan ja talouden käsittein, vaikka kyse on aikuisten oppimisesta, kehittymisestä ja kouluttautumisesta.

Aikuiskoulutuspolitiikan teemanumeroon haetaan kriittisiä ja monipuolisia tekstejä, jotka käsittelevät aihetta eri näkökulmasta. 'Politiikalla' tarkoitetaan laajasti politiikan tekemistä, toimintapolitiikkoja ja erilaisia kamppailuja aikuiskoulutukseen kytköksissä olevilla kentillä.

Politiikkaa tekevät monet tahot kansallisesti ja ylikansallisesti. Politiikan kohteina ovat niin ikään eri tasojen toimijat, rakenteet ja instituutiot, viime kädessä kansalaiset.

\section{SIVISTYSTYÖ PLANETAARISTEN \\ KRIISIEN AJASSA, 1/2021}

Planetaariset kriisit haastavat etsimään uusia ajattelun ja oppimisen toimintatapoja. Miten sivistystyö voisi edistää sosiaalista, taloudellista ja ekologista kestävyyttä?

Teemanumerossa keskitytään ekososiaaliseen sivistykseen, jota tarkastellaan planetaarisuuden ja kestävän kehityksen näkökulmista.

Ekososiaalinen sivistys on muutosvoima, jossa yhteisöt luovat yhdessä laajenevan, demokraattisen, kaiken elävän biologista ja kulttuurista monimuotoisuutta kunnioittavan tilan. Työ ja ammatillinen toiminta kuuluvat ekososiaalisen sivistyksen tarkasteluun, sillä ne ovat vahvasti sidoksissa suomalaisen sivistyskäsitteen määrittelyihin. Samalla ne ovat perustavia vapaan sivistystyön identiteetille.

Teemanumero juhlistaa Sivistystyön vapaus ja vastuu (SVV) -ohjelman kymmenvuotisuutta. SVV tukee vapaan sivistystyön tutkimusta ja koulutusta, alan tutkijoiden ja toimijoiden vuorovaikutusta sekä yhteiskunnallista vaikuttamista.
Teemanumeron tekstit voivat etsiä vastauksia esimerkiksi siihen,

- miten aikuiskoulutusta koskevia päätöksiä tehdään, miten syntyvät linjaukset aikuisten kouluttamiseksi ja mitä aikuiskoulutuspolitiikalla tuotetaan

- missä osaamisen kehittämisen politiikkaa tehdään ja kenen ehdoilla

- millaisia toimijoita tutkijat ovat suhteessa aikuiskoulutuskoulutuspolitiikkaan

- millaisilla työkaluilla ja tekniikoilla politiikkoja toteutetaan

- miten politiikat vaikuttavat instituutioihin, rakenteisiin ja käytänteisiin.

\section{Aikataulut: tiedeartikkelien käsikirjoitukset viimeistään 29 toukokuuta; näkökulmat, pu- heenvuorot ja kirja-arviot ehti- vät viimeistään 7. elokuuta.}

Toimituskunnassa numerosta vastaa Nina Haltia.

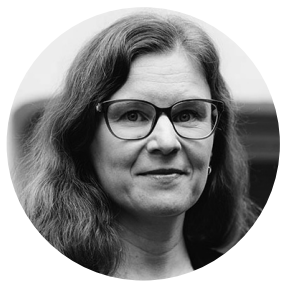

Teemanumeroon etsitään käsikirjoituksia, jotka käsittelevät ekososiaalista sivistystä, planetaarisia kriisejä tai kestävää kehitystä aikuiskasvatuksen ja vapaan sivistystyön kontekstissa. Tekstit voivat vastata esimerkiksi

- sivistyksen ja vapaan sivistystyön rooliin planetaarisissa kriiseissä ennen, nyt ja tulevaisuudessa

- ekososiaalisen sivistyksen rooliin globaalien haasteiden aikakaudella

- vapaan sivistystyön suhteeseen työhön, talouteen ja ammatteihin.

Käsikirjoituksia pyydetään aikuiskasvatusalan toimijoiden ohella köyhyys-, yhteiskunta-, ilmasto-, ympäristö- sekä media-alan asiantuntijoilta.

Toimituskunnassa numerosta vastaa Hanna Toiviainen.

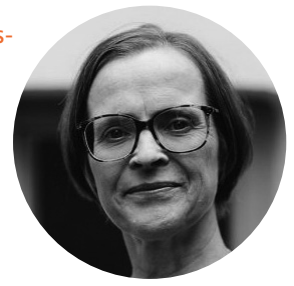


Tutkimusta tehdään, jotta ymmärretään paremmin todellisuutta. Joskus lisääntynyt ymmärrys saattaa johtaa siihen, että vallalla oleva kehityskulku pitää kääntää.

- Millaisen roolin tutkija ottaa yhteiskunnassa törmätessään korjaamista vaativiin epäkohtiin?

- Kuinka akateemisuus ja aktivismi sovitetaan yhteen?

- Onko olemassa tutkimusta, joka kantaaottavuudessaan lähentyy aktivismia?

Akateemisen aktivismin teemanumerossa paneudutaan tutkijan ja aktivistin roolien väliseen jännitteeseen.

Tutkimuksen poliittisuus, vahvistuva eettisyyden tarve monimutkaistuneessa maailmassa ja dystooppiset tulevaisuuskuvat vaativat tutkijaa asemoitumaan uudella tavalla yhteiskunnassa.

Näkökulmana aktivismiin voi olla esimerkiksi elämän edellytysten jatkuminen, tasa-arvon kysymykset tai aktiivinen kansalaisuus.

Käsikirjoitukset voivat olla yhtä hyvin aikuiskasvatuksen ytimessä kuin tieteiden rajat ylittäviä, teoreettisia, käsitteellisiä tai empiirisiä.

Toimituskunnassa numerosta vastaa Arto O. Salonen.

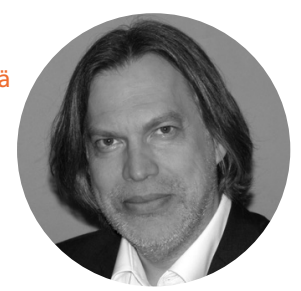

\section{NÄIN TARJOAT KÄSIKIRJOITUSTA TEEMANUMEROON}

- Tutustu Aikuiskasvatuksen kirjoittajaohjeisiin.

- Mieti erityisesti, miksi käsikirjoituksesi on ajankohtainen juuri nyt

ja minkä asian haluat sillä tuoda keskusteluun.

- Lähetä artikkelin käsikirjoitus toimitukseen (terhi.kouvo@kvs.fi).

Lisätiedot: toimituspäällikkö Terhi Kouvo, 0400396 437, terhi.kouvo@kvs.fi

\section{Kaikkien-malli}

Vaikuttava ja oppijalähtöinen perustaitojen koulutusmalli työikäisten arjen parantamiseksi.

- Oppijalähtöisyys ja vaikuttavuus: Sisältö ja tavoitteet suunnitellaan yhdessä oppijoiden kanssa. Oppija valitsee ja aikatauluttaa arkensa parantamiselle henkilökohtaisen tavoitteen. Tavoitteen saavuttamiseksi on käytettävä yhtä tai useampaa perustaitoa. Tarve arjen parantamiseen motivoi, antaa oppimiselle syyn ja suunnan.

- Paikallisuus. Koulutus linkitetään paikalliseen yhteisöön. Vahvistetaan oppijoiden yhteyksiä toimintaympäristöönsä.

- Skaalautuvuus. Sopii käytettäväksi erilaisissa ympäristöissä ja kanavissa, esimerkiksi harrastusryhmässä tai etäkoulutuksena.

Yhteiskunta tarvitsee kaikkia - perustaidot kuuluvat kaikille Kaikkien-malli Kaikkien-mallin esittely ja kouluttajan opas käyttöönottoon: kansalaisenperustaidot.fi / kaikkienmalli.fi

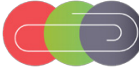

KANSALAisen PERUStaIdot 